\title{
Sisällön asiantuntijoista verkkovirtuooseiksi
}

\author{
Ammattikorkeakouluopettajien \\ h a a s te it a
}

täydennyskoulutuksen

\author{
Tuomo Norvanto
}

\begin{abstract}
Aikuisopettajan roolin muuttuessa opetuksen keskiöstä varjoon, oppimisympäristöjen mahdollisuuksien luojaksi, on opettajalle syntynyt tunne asemansa heikkenemisestä - henkisestä häviämisestä. Aiemman osaamisen perustana ollut sisällöllinen hallinta jää sivuraiteille ja pääosaan nousee uudenlainen osaaminen: oppijalähtöinen oppimisympäristöjen suunnittelu ja tietoverkkojen hyödyntäminen opetuksessa. Mitä opiksi?
\end{abstract}

\begin{abstract}
A mmattikorkeakoulun opettajan rooli elää jatkuvassa muutoksessa. Valtaosa opettajista on siirtynyt opisto-opettajista suoraan ammattikorkeakouluopettajaksi. Tämä askel on merkinnyt opettajan työnkuvassa painopisteen muutosta sisällön asiantuntijasta ensin itseohjautuvien oppimismahdollisuuksien luojaksi ja edelleen verkkoympäristöjen suunnittelijaksi ja toteuttajaksi. Kuinka löytää opettajan työhön tasapaino aiemman opetustyön perustana olleen sisällöllisen osaamisen, uusien oppimisympäristöjen suunnittelun ja verkko-opetuksen mahdollisuuksien kanssa? Tämä kysymys on ammattikorkeakoulun opettajien täydennyskoulutuksessa keskeinen.

Ammattikorkeakoulun opettajille on järjestetty paljon täydennyskoulutusta verkko-opetuksen käyttöönotosta. Täydennyskoulutuksen suunnittelijana olen havainnut, että verkkoympäristön suunnittelukoulutuksen toteutuksessa kohtaavat kolmenlaiset odotukset: opettajan, tilaajan ja koulutuksen järjestäjän. Moninaiset odotukset luovat jännitteitä koulutuksen toteutukseen ja vastaanottamiseen. Kerron tässä kokemukseni perusteella esille nousseita kehittämisajatuksia, joilla ammattikorkeakoulujen opettajille suun-
\end{abstract}

natussa verkkoympäristön suunnittelukoulutuksessa voitaisiin saada paremmin kohtaamaan kaikkien kolmen osapuolen, opettajan, tilaajan ja koulutuksen järjestäjän, tavoitteet verkko-opetuksen kehittämiseksi, jotta verkko-opetus palvelisi mahdollisimman hyvin koulutuksen ydintä eli yksittäistä opiskelijaa.

\section{Opettajat mutoksen airuena}

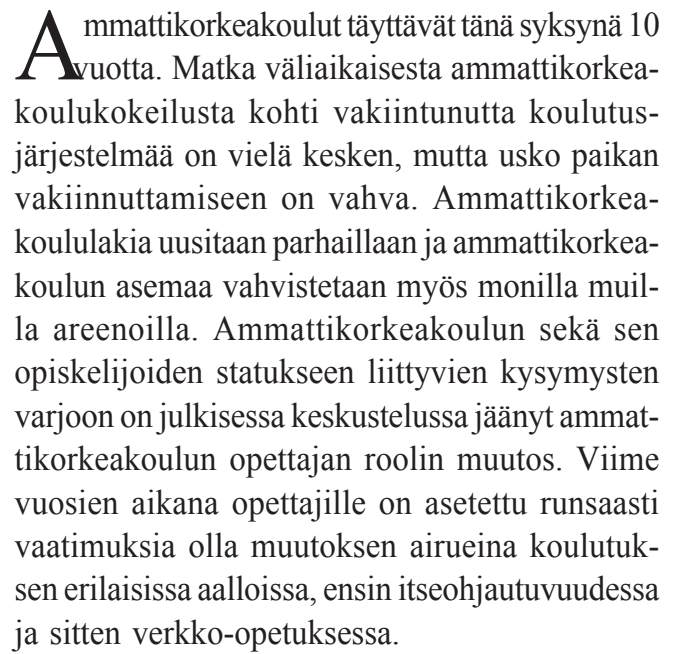




\section{Opisto-opettajasta a mmattikorkeakouluopettajaksi}

$\mathrm{M}$ onet ammattikorkeakoulun opettajat edustavat opetuksen lähtökohdissaan ja opetusnäkemyksissään opistokoulutuksen perinnettä. Opettajat ovat voineet toimia ennen ammattikorkeakoulu-uraa esimerkiksi kauppaopiston, teknillisen opiston tai sosiaali- ja terveysalan oppilaitoksen opettajina. Näissä oppilaitoksissa hankitut kokemukset ja käytännöt elävät opettajien tottumuksissa eikä esimerkiksi opiston nimenmuutos kauppaopistosta liike- ja talouselämän sekä hallinnon koulutusyksiköksi muuta hetkessä opettajan toimintaa toiseksi, vaikka itse organisaatio laajenisi monialaiseksi yhteisöksi, jossa on mukana useita koulutusyksiköitä saman mentaalisen kyltin alla.

Opiskelijan roolissa keski-ikäinen ammattikorkeakoulun opettaja on läpikäynyt auktoriteetin varaan rakentuneen koulutuskulttuurin kansakoulusta yliopistoon. Tässä koulun kulttuurissa opettaja puhuu ja opiskelija kuuntelee. Opiskelija osoittaa kuuliaisuutensa kokeissa ja tenteissä hyvinä arvosanoina, jotka ovat mitanneet sitä, kuinka hyvin opiskelija on omaksunut hänelle esitetyt faktat. Opettajan sana on ollut hyvin usein ainoa totuus.

Näistä lähtökohdista opettajat arvostavat nimenomaan sisällön asiantuntijaa. Pedagoginen harrastuneisuus ei ole ollut yleensä opetuksen selkäranka. Opettajan pedagoginen osaaminen on ollut puhumista, selittämistä ja kertomista, toisin sanoen esittämistä luokalle. Opetusta on tukenut oppikirja ja suunnittelua opettajan työkirja. Aktivointitavat, palautteenanto ja erilaista opetusta erilaisille yksilöille tarjoavat opetusvaihtoehdot ovat jääneet vähemmälle huomiolle. Opetuksen suunnittelu on ollut pääosin lähiopetuksen suunnittelua. Opiskelijoiden osaaminen on mitattu yleensä tentein, kirjallisin tehtävin ja harjoituksin.

\section{Opettajan työnkuva monipuolist un ut}

Amattikorkeakoulutuksen kokeiluvaiheen tajuttiin heti, että on syntymässä uusi opettaja-

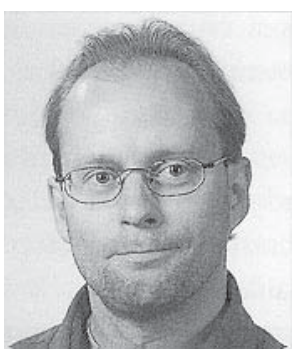

Tuomo Norvanto

tyyppi, ammattikorkeakouluopettaja, joka tarvitsee uudenlaisia valmiuksia pärjätäkseen tietoyhteiskunnassa. Jorma Ekolan (toim.) Ammattikorkeakoulupedagogiikka (1994) ilmestyi oikeaan saumaan. Monilla opettajilla oli halu tietää, mitä hänen tulisi osata ja kuinka opettaa ammattikorkeakoulussa.

Opisto-opettajan roolissa keskiössä ollut sisällön asiantuntija joutui sivummalle ja tilalle astui oppimismahdollisuuksien luoja. Opettajalta odotettiin aivan toisenlaista osaamista kuin mihin hän oli koulun kulttuurissa ensin opiskelijana ja sittemmin opettajana tottunut. Aiemmin työn lähtökohtana ollut voimakas sitoutuminen ainekohtaisten sisältöjen oppimiseen ja niiden hallintaan ei ollutkaan enää opettajan työn ensisijainen kohde. Nyt vaadittiin itsenäisen opetustyön muuttamista opettajien väliseksi yhteistyöksi, työelämäyhteyksien rakentamista ja syventämistä sekä opiskelijalähtöisten opetuksen suunnittelutaitojen osaamista. Kenelle tahansa ammattilaiselle näin syvällinen oman työnkuvan muutos aiheuttaa voimakkaita kasvukipuja. Opettaja oli pudotettu kateederilta kanveesiin. Opettajan perusosaamista eli sisältöjen opettamista ei arvostettu enää entisellä tavalla, ja täten moni opettaja tunsi olevansa tyhjän päällä. Aiempi osaaminen ei ollut arvossa ja uutta osaamista ei ollut ehtinyt rakentua.

Amattikorkeakoulukokeilussa oli 1990-lunan ja pedagogiikan ohjenuorana itseohjautuvuus. Tämä tuli esille sanomalehtikirjoittelussa, kahvipöytäkeskusteluissa, rehtorin sanavalinnoissa ja painotuksissa, opettajien toimintatavoissa ja koko toimintaympäristössä. Itseohjautuvuus juur- 
tui oppilaitosten omiin opetussuunnitelmiin ja se eli myös toimintaympäristön piilo-opetussuunnitelmassa oletuksina ja odotuksina. Opetukseen ja opetusjärjestelyihin itseohjautuvuus sekä siitä johdetun uuden opettajuuden malli löivät voimallisesti leimansa. Monitieteisyys yhden sisällön taitamisen sijaan, yksittäiset teemat opintojakson sisällöllisen koherenssin asemesta ja painopisteen siirtyminen frontaaliopetuksesta opiskelijoiden itsenäisiin ja ohjattuihin projekteihin olivat opettajan työnkuvan keskeisiä puolia. Opettajan roolissa korostui itseohjautuvuutta tukeva ohjaaja ja projektin vetäjä. Opiskelijoiden työharjoittelujaksojen järjestely, työelämäsuhteiden käynnistys ja ylläpito sekä kokoukset, joissa pohdittiin ammattikorkeakoulun ja oman osaston toimenkuvaa, täyttivät suurelta osin opettajan työaikaa.

Ammattikorkeakoulun opettajan rooli on ollut ammattikorkeakoulukokeilun alusta lähtien korostetusti laajempi kuin perinteisen opisto-opettajan. Tämä muutos on kunkin opettajan työssä tullut väistämättä eteen ennemmin tai myöhemmin, vaikka hän toimisi hyvinkin perinteisillä opetusaloilla kuten kielissä tai kotitaloudessa, joiden voisi ajatella olevan syrjässä monialaisten opettajatiimien työkentästä. Ammatillisten ja sivistävien oppiaineiden opettajien välillä on varmasti edelleen erilaisia näkemyksiä siitä, kuinka pitkälle tiimimäiseen ja projekteja ohjaavaan opettajan rooliin pitäisi mennä, mutta ammattikorkeakoulun kentällä laaja-alainen ja ohjaava opettajuus elää vahvana edelleen.

\section{Opettajan työn ymmärtäminen ja ymmärryksen sovittaminen}

$\mathrm{K}^{\mathrm{n}}$ un opettajat olivat vielä omaksumassa uutta teiin undet odotukset: oppia verkko-ohjajaksi tettiin uudet odotukset: oppia verkko-ohjaajaksi ja verkkoympäristöjen suunnittelijaksi. Opettajille on ollut erittäin haasteellista lähteä mukaan oppimaan uutta verkko-opetuksesta tilanteessa, jossa oma oppilaitos etsii paikkaansa koulutusjärjestelmässä ja sitä myötä myös opettajat joutuvat tarkastelemaan työnkuvansa peruspilareita. Koulutusta tilaava organisaatio ei ole löytänyt ratkaisuja, joilla opettajille annettaisiin aikaa, selkeitä tavoitteita ja toimintatapoja keskittyä jär- jestettävään koulutukseen. Tällöin tilatusta koulutuksesta syntyy opettajille helposti vain uusi tehtävä, jonka joutuu tekemään arkisen opetusja hallintotyön päälle. Koulutuksen tilaaja ei ole useinkaan varannut opettajille riittävästi aikaa paneutua koulutukseen. Opettajien perehdyttäminen organisaation verkkokoulutuksen visioon ja näkökulmien avaaminen verkko-opetuksen hyötyihin opettajan työssä ja opiskelijoiden oppimisessa tukisivat ratkaisevasti opettajien osallistumista järjestettyyn koulutukseen.

\section{Koulutuksen solmukohtien ava a minen}

$\mathrm{V}$

erkkokoulutuksen vastaanottamisessa opettaja joutuu väistämättä tilanteeseen, joka ei ole henkisesti miellyttävä. Oma osaaminen joutuu kyseenalaiseksi. Opettajan on myönnettävä olevansa verkko-opetuksessa noviisi, jolla on paljon opittavaa. Opetuksen suunnittelutaidot ovat riittäneet vielä toimittaessa itseohjautuvuutta korostavassa opettajan työssä, mutta verkko-opetuksen suunnittelu ja toteutus edellyttävät jälleen uuden oppimista. Kuilu oman osaamisen ja tavoiteltavan osaamistilan välillä on usein suuri. Tämä aiheuttaa opettajalle riittämättömyyden ja turvattomuuden tunteita. Tämä tilapäinen oppimiskuilu ja siihen liittyvät ahdistavat tunteet tulisi tiedostaa ja käydä ne läpi koulutuksen alussa. Koulutuksen tavoitteiden selkeyttäminen (opettaja, tilaaja ja järjestäjä) avaa usein solmukohtia, joiden jälkeen orientointi koulutukseen ja realististen odotusten asettaminen omalle oppimiselle asettuvat kohdalleen. Koulutukseen orientointijakso on oppimisen lämmittelyvaihe, jonka onnistuminen antaa kaikille osapuolille varmuuden koulutuksen oikeasta suunnasta.

Seuraavana ongelmana on opettajien ja koulutusta järjestävän tahon erilainen näkemys oppimiseen ja oppimisympäristöjen suunnitteluun valittujen sisältöjen merkityksestä koulutuksen kokonaisuudessa. Useat opettajat ovat suorittaneet koulutukseen tullessaan melko hiljattain opettajan pedagogiset opinnot, joiden painopisteenä on ollut viime vuosina opettajan uusi rooli konstruktivistisen oppimisnäkemyksen valossa. Kun verkkoympäristön suunnittelukoulutuksen lähtökohtana on vastaava näkemys, tämän 
asian nostaminen esille heti koulutuksen alkuvaiheessa on nostanut monen opettajan mielessä vastustuksen. Kyllästymispiste konstruktivismiin on tullut hyvin usein esille opettajien antamissa palautteissa ja opettajien näkökulmasta siitä on vaikea ammentaa enää uutta.

Opettajien odotukset etenkin koulutuksen alussa keskittyvät sen sijaan konkreettiseen osaamisen kohottamiseen tietoteknisissä valmiuksissa, kuten www-sivujen teossa sekä valitun oppimisalustan haltuunotossa. Tämän faktan edessä verkkoympäristöjen suunnittelukurssien luonnetta ja etenkin konstruktivismin painopistettä yhtenä koulutuksen sisältönä tulisi ajatella uudella tavalla. Koulutuksen alkuvaiheeseen on tuotava yhä enemmän esimerkkejä toteutetuista verkkokursseista mielellään aiempiin verkkokoulutuksiin osallistuneiden opettajien kertomina. Verkkokurssien esimerkit ja niiden tekemiseen liittyvien kokemusten välittäminen motivoivat muita opettajia ja helpottavat näkemään, kuinka opettajat voivat omassa työssään hyödyntää verkkoympäristöä. Samalla opettajilta hälvenee pelko siitä, että he eivät opi enää käyttämään uusia välineitä tai että he eivät omaksu verkko-opetuksen pedagogisia keinoja.

Oppimisnäkemyksien pohtiminen ja niiden läpinäkyväksi tekeminen omaa opetusta ohjaavina tekijöinä on koulutuksessa tärkeää ottaa esille, mutta se kuinka tämä tehdään on vieläkin tärkeämpää. Näkemykseni mukaan oppimisnäkemys pitää kirjoittaa kurssin käsikirjoitukseen yhdeksi läpikäyväksi juoneksi osaksi koulutuksen punaista lankaa, joka on oppimista tukevan oppimisympäristön suunnittelu ja siihen liittyvät valinnat ja niiden perustellut ratkaisut.

Oppimisnäkemys on tärkeä osa oppimisen suunnittelua, mutta se on saatava elämään opettajan ajattelussa ja käytänteissä, jotta se näkyy oppimisympäristön kokonaissuunnittelussa perusteltuina valintoina.

$\mathrm{K}$ olmantena sudenkuoppana verkkoympärisöjen suunnittelukursseilla on tullut esille oppimisalustan tekninen haltuunotto ja verkkoympäristön rakentaminen. Opettajien tietotekninen taso on kursseille tultaessa varsin kirjava. Tekniikan koulutusyksiköiden opettajat osaavat www-sivujen tekemisen ja erilaisten verkossa toi- mivien tiedostomuotojen käsittelyn hyvin jo kurssille tultaessa. Uuden oppimisalustan tekninen hallinta onnistuu vahvan teknisen perustan myötä periaatteessa helposti, mutta tällä opettajaryhmällä on hyvin usein kriittinen suhtautuminen tarjottuun verkkoympäristöön. Heiltä kuulee usein näkemyksen, että tämä alusta ei taivu omiin käsityksiin verkkoympäristön käytöstä ja että tässä verkkoympäristössä ei ole mahdollista tehdä sitä tai tätä. Rakentavampi vaihtoehto olisi katsoa, kuinka alustaa voisi käyttää omassa opetuksessa sen mahdollisista rajoitteista huolimatta. Mikäli opettaja on tottunut välittämään opetusmateriaalia omien www-sivujensa kautta, hän voisi tutkia, kuinka valittu verkkoympäristö voisi tukea opetuksen hallinnointia ja opiskelijoiden vuorovaikutteista ja yhteistoiminnallista oppimista verkossa.

Suurimmalle osalle koulutukseen tulevista opettajista www-sivujen tekeminen ja verkkoympäristöt ovat sen sijaan outoja. Eri tilaajien kanssa on syntynyt käytäntö siitä, että ennen varsinaisen suunnittelukoulutuksen alkua halukkaat opettajat saavat parin päivän koulutuksen wwwsivujen tekemisestä. Tällä edeltävällä koulutuksella on haluttu varmistaa, että opettajien lähtötaso on riittävä verkkoympäristön suunnittelukurssin tarkoituksenmukaiseen ja hyödylliseen opiskeluun.

Valtaosa opettajien antamasta palautteesta kertoo, että oppimisalustan käytön tekninen koulutus on kautta linjan ollut hyvää, mutta sitä ei ole ollut riittävästi ja sitä koskevan koulutuksen ajoittaminen ei ole täysin onnistunut. Olemme pyrkineet kuuntelemaan opettajien toiveita ja lisänneet koulutusohjelmaan vielä koulutuksen käynnissä ollessa teknistä koulutusta käytettävästä oppimisalustasta. Sitä on lisätty etenkin kurssin loppupuolelle, minne verkkoympäristön rakentaminen painottuu. Alustan tekninen opetus kulkee kurssilla johdonmukaisesti kurssin loppuun saakka, mutta opettajat eivät välttämättä näe tätä jatkumoa omassa opiskelussaan. Yhtenä syynä tähän teknisen koulutuksen hahmottamisharhaan on se, että opettajilla menee kurssin alussa ja vielä keskivaiheillakin paljon aikaa päätöksen tekemiseen siitä, mikä on heidän kehittämishankkeensa omassa ja koulutusyksikön opetuksessa. 


\section{Verkkostrategiat näkyviksi}

$T_{k}$ ähän mennessä toteutetuissa ammattikorkeakoulujen ja Turun yliopiston täydennyskoulutuskeskuksen välisissä verkkokoulutushankkeissa on ollut selkeänä pulmana se, että koulutukseen tulevat opettajat eivät ole riittävän tietoisia niistä tavoitteista, joita heidän organisaationsa ovat asettaneet koulutukselle. Heille ei myöskään ole syntynyt käsitystä oman organisaationsa verkkostrategiasta.

Tilaajan ja opettajien verkkokoulutuksen hyödyntäminen lähtisi paremmin käyntiin, mikäli tilaaja kartoittaisi ja profiloisi tarkemmin kohderyhmänsä eli osallistuvien opettajien verkkohankkeet jo varhaisessa vaiheessa ennen varsinaisen koulutuksen aloittamista. Ammattikorkeakoulun verkkostrategian sanallistamisen, toiminnallistamisen ja tiedottamisen kautta eri koulutusyksiköiden opettajat tuntisivat paremmin, mihin oma ammattikorkeakoulu verkko-opetuksellaan pyrkii, ketä sillä pyritään tavoittamaan, kuinka oma toiminta on yhteydessä kansallisiin ja kansainvälisiin virtuaalihankkeisiin ja mitä ammattikorkeakoulujen opettajat voivat hankkeessa oppia ja mitä heillä on annettavana verkko-opetukseen oman osaamisensa kautta. Koulutukseen sitoutuminen jämäköityy, kun verkkostrategia on mahdollisimman monelle kirkas. Oppilaitos tuntee tällöin hyvin tehtäväkenttänsä verkko-opetuksessa.

Ammattikorkeakoulu pyrkii tilauskoulutuksella saavuttamaan mahdollisimman nopean hyödyn. Opettajien ulkopuolinen koulutus nähdään lääkkeenomaisena ratkaisuna, joka vie ongelmat kerralla pois ja verkko-osaaminen saadaan kertaostolla organisaatioon. Mielestäni parempaan tulokseen päästäisiin kuitenkin pidemmän kaavan kautta eli tutustumalla perusteellisesti oman talon verkkolinjauksiin, ja ellei niitä ole, ne luotaisiin kansallisten strategioiden pohjalta. Tällä tavalla voitaisiin löytää keskeiset verkko-opiskelun ja -opetuksen lähtökohdat omassa oppilaitoksessa.

Henkilöstön perehdyttäminen ajatuksellisesti tulevaan koulutukseen ja sen kytkeytyminen talon omiin verkkovisioihin antaisivat tukevan perustan valita koulutukseen osallistuvat opettajat ensiksi pilottiin ja tämän jälkeen lähivuosien aikana järjestettäviin koulutuksiin. Koulutukseen rekrytointivaiheessa olisi myös hyvä pohtia, syntyisikö yksiköistä tai yksiköiden välisen yhteistyön kautta sopivia opettajatiimejä, jotka voisivat tehdä yhdessä verkkohanketta ja jotka voisivat levittää koulutuksen tuottamaa asiantuntemusta sisäisenä koulutuksena oman yksikön henkilöstölle. Valintatilanteessa olisi myös mahdollista tarkastella, millaista osaamista yksikkö tarvitsee verkkoympäristöjen suunnittelusta ja toteutuksesta ja tarvitseeko kaikkien osallistujien hankkia tietoa kaikista koulutuksen osa-alueista. Voitaisiin myös pohtia, voisiko koulutukseen osallistuvan tiimin työnjaolla pyrkiä siihen, että tiimi pystyisi toimimaan työryhmänä myös koulutuksen jälkeen. Näin syntyneessä työryhmässä on tietotaitoa oppimisen lainalaisuuksista, oppimisympäristöjen kokonaissuunnittelusta, verkkokurssin teknisestä toteutuksesta sekä oppisisältöjen toimittamisesta. Kenties yhden opettajan ei tarvitsikaan hallita kaikkia kyseisiä alueita suvereenisti, vaan hänelle riittäisi verkkoympäristön suunnittelun vaiheiden kokonaistuntemus ja erikoistuminen hänelle sopivimpaan osaamiseen ja sen jakamiseen yhteisissä verkkohankkeissa.

\section{Verkkopedagogiikan käyttöönotto vaatii aikaa ja työtä}

Ammattikorkeakoulut ovat pyrkineet tekemään "verkkomullistuksen" yhdessä yössä tutkimatta tarkoin omia rakenteitaan ja sitä, mitä verkkoopetuksen tulo merkitsee opiskelijoille, opettajille ja hallinnolle. Verkko-opetuksen valitseminen osaksi oppilaitoksen opetusta merkitsee muutosta oppilaitoksen kaikilla tasoilla jokaisen toimijan roolissa ja tehtävissä. Tähän organisaation tekemän valinnan tuomaan muutokseen kannattaisi panostaa yhä enemmän verkko-opetuksen suunnittelussa ja siihen liittyvän koulutusyhteistyön kehittämisessä tilaajan ja toteuttajan välillä. Ilman sitoutunutta opettajaa ei synny hyvää verkko-opetusta ja ilman verkkostrategiaa ei synny pitkäjänteistä verkko-opetuksen kehittämistä. Ilman näitä kahta yksittäinen verkko-opiskelija harhailee tiedon valtaväylältä poikenneena verkkoliftarina ilman selkeää määränpäätä. 